\title{
Online Branding: an Antipodean Experience
}

\author{
Jack Yan ${ }^{1}$ \\ ${ }^{1}$ CEO, Jack Yan \& Associates, PO Box I4-368, Wellington 604I, New Zealand \\ jack.yan@jyanet.com
}

\begin{abstract}
Australia and New Zealand enjoy high per-capita internet usage and have a small group of organizations that have succeeded globally on the web despite less capitalization and fewer resources. The author, a web pioneer and identity expert, examines how they have instead leveraged brands and intellectual capital, and looks at implications for all firms wishing to incorporate a web element to their marketing.
\end{abstract}

\section{The theory of identity and branding}

\section{I.I Introduction}

The web has impacted on developed nations and the way we conduct business. The structure of commerce has changed significantly with the rise of infomediaries [I] and portals but one constant has been the need for the branding of goods and services in online and cross-media ${ }^{1}$ firms. Many web business failures are tied in with poor branding and as more of the world goes online, this area seems even more important to organizations. With the increased reach of the web, companies are finding proper branding more vital for international dealing. Similarly, branding has become more important in ensuring value for marketing dollars with numerous high-profile ebusiness failures [2] and the end of the late-I99os' online gold rush.

'Wired' consumers have been the target of these branding efforts. Since the midI990s, traditional firms going on to the web and web-only enterprises have tried to woo them using traditional and emerging branding models. In some cases, novelty, rather than long-term branding considerations, were the initial and only attraction. This paper looks at what has made successful, global brands in Australia and New Zealand. It further addresses how they could win future consumers using the internet and other media.

1 The author uses this term to mean organizations that have online (web) and offline (bricksand-mortar, print, TV) presences, adapting from the publishing industry. 


\section{I.2 What is branding?}

With more practitioners in branding, the offline phenomenon of experts disagreeing on the definition of the word has made its way online. [3] One authority is Wally Olins, chairman and co-founder of identity consultancy Wolff Olins, who states that the brand began as "the emanation of the company's products as far as one audience was concerned ... the customer." [4, 5] But the company (or the non-profit organization, or even the nation) [6] is now becoming a brand, representing an "attitude". The "totality of the corporate whole" is represented by the brand. [5]

In other words, the brand has an outward focus, i.e. it is a representation of an organization's vision. It is part of a larger framework of "identity", or:

the explicit management of all the ways in which the organization presents itself through experiences and perceptions to all of its audiences. [7]

Identity begins with a vision or a corporate raison d'être. Some organizations use a mission statement, but research by the author [8] shows that a slogan is equally powerful, such as Saturn's "A different kind of company. A different kind of car," and Caltex's "We're pumping," the latter used in New Zealand in the late I990s for relaunching that company's brand. The important aspects are:

(a) the uniqueness of the statement relative to other entrants in the market-place;

(b) the ability to summarize an 'attitude' of the organization.

These elements are then linked with other aspects of the brand, such as its symbol or logotype (or the proprietary brand assets). Audiences, including internal audiences based on Olins's latest thinking on branding, come to learn the association between the attitude and the symbol through a careful communications' campaign.

Semiotics are key. [9] Symbols, logos, etc., signify certain things that form mental pictures in our mind when we interpret them. The campaign ensures that the correct pictures are formed and that incorrect or earlier ones are replaced. [IO] Repeated exposures reinforce meaning, which is why consistency in branding is important.

This leads to brand equity [II] - the added value which a brand endows a product - divided into the associations and proprietary assets mentioned, plus brand loyalty, perceived quality and brand awareness. [12] As audiences - whether they are shareholders, future customers, students or any other group - select or think of the brand more frequently, they ultimately contribute to the organization's business performance in economic or strategic terms. [13, I4]

Given all these activities involve the brand, it is hard to pinpoint exactly what "branding" is. "Identity", as defined, must include every element from vision through to image because these are ways the organization presents itself. Some authors like to include the entire process for branding, but that would be contrary to the established usage of "identity". In the literal sense, of branding animals, it comes with the labelling. Its origins began in the nineteenth century with the bestowing of names for common products, usually commodities, while advertising allowed companies to speak to consumers directly. [15] Therefore, branding is restricted to exercises which com- 
municate the identity to audiences. It is the realization of the explicit management in Olins's quote, therefore:

the methods in which the organization communicates, symbolizes and differentiates itself to audiences. [I6]

The brand may be thought of as "an inclusive term which refers to a product or service. It includes its trademark, its name, its reputation and the sensual and emotional buttons surrounding it, most often created by advertising." [I7]

\section{I.3 The modern wired consumer}

Today's web has parallels to the advent of television in that organizations do not yet know the ideal method of reaching audiences. Olins forecasts that "these teething troubles are going to last for a long time." [5] However, the consumer psychological process remains largely the same. [IO] The principal difference is that more experienced audience members often seek information online and are not exposed to it 'unexpectedly', with the exception of online advertising. Some younger internet users, having grown up with advertising and computers, take the web's presence for granted and browse with tightly defined criteria. The question is how an organization ensures its brand is at the top of the user's consideration set and, on a related note, how it can appear in search engines and portals prominently. As stated by Ries, "Internet brands are invisible until you input the brand name into the keyboard. If you don't know the brand name and how to spell it, no sale can happen. Therefore, online, name recognition is paramount.” [I8]

Organizations must find ways of reaching consumers and becoming their preferred or only source if their online ventures are to be successful. Even if there were agreed definitions on branding, there is still the issue of practice.

There is an additional challenge. Brands have become so high profile that the public is fascinated by the organizations behind them. Corporate citizenship has become important. The flip side of branding is that companies that employ sweatshop labour and other unethical practices are more easily targeted. Modern consumers fight establishment brands, preferring niche players partly because of increased segmentation, as sales leaders Nike and Levi's found in the late-1990s. [19, 20] This suggests that organizations must not risk appearing too overwhelming and retain an entrepreneurial style.

\section{I.4 Australia and New Zealand}

The author focuses on Australia and New Zealand. These two countries are developed and economically free, [2I] although the combined population is only roughly 20 million. However, Australia's area is equal to that of the United States. Some organizations from Australasia wishing to compete online cannot realistically focus on a 
domestic market if they wish to have sufficient viewer numbers or customers. Sources of capital are also expectedly fewer. Currency differences, not least the drop in the value of the Australian and New Zealand dollars against the US dollar and other major currencies over 2000, mean that organizations have had to get more value from their earnings, especially if they relied on infrastructure in the United States. To provide them with reach, they have had to adopt careful branding strategies, cultivating their presences online against much larger players.

This is typical of countries that do not have a ready access to capital, despite its mobility. [22] The successful organizations there have to leverage their intangible assets, in this case, their brands, and, by definition, part of their intellectual property. If intangibles are the "scarce resource" of the twenty-first century, [22] then there are many lessons to be learned from this part of the world.

Relative to the United States, the Australasian web has been quieter. Despite contemporaneous availability, the smaller population meant there were fewer taking advantage of it. Although there is a very high per capita internet use, the numbers do not match that of Silicon Valley. Differing government policies meant that Australia and New Zealand did not duplicate the degree of innovation seen in Sweden, that resulted in many popular sites visited by international audiences. Flotations of dot coms barely registered in the news.

\section{I.5 Structure}

The following section features an analysis of the players, detailing specific efforts and how they have affected the internet public. The paper concludes with the lessons they provide for future branding for businesses.

\section{The practice}

\section{I The identity and branding model}

The identity and branding model was developed after a full analysis of the literature and research into branding practice (see Fig. I overleaf). [23] This model links vision, research, exposition and image with business performance. Image is the consequence of branding activity and deals with how audiences have reacted. Each of these elements is analysed qualitatively here. 


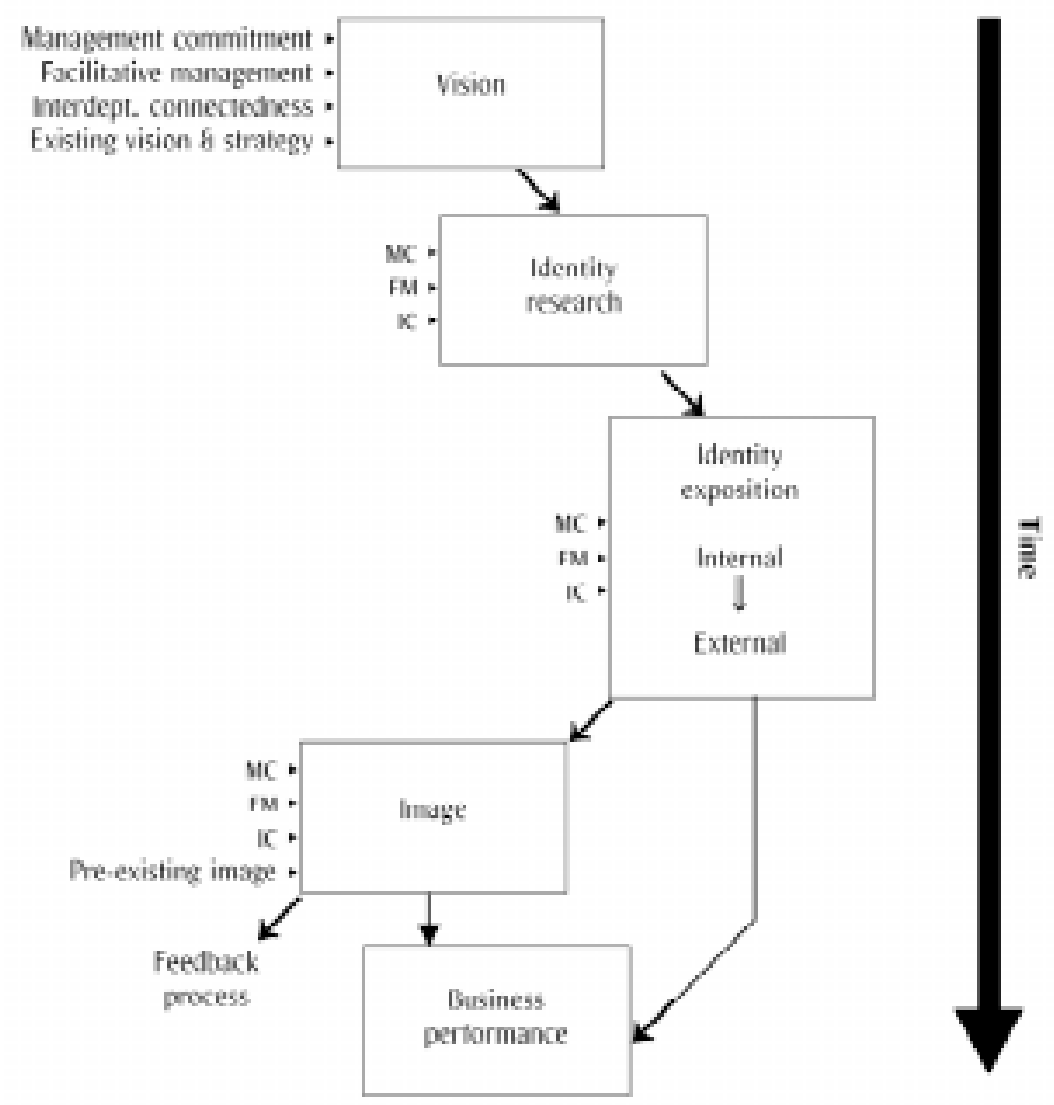

Fig. I. The identity and branding model, from JY\&A Consulting: JY\&A Consulting Profile. JY\&A Consulting, Wellington (2000). The model blends the author's identity research with the principles of market orientation

\subsection{Vision}

Vision is crucial, according to earlier literature. [7, 24] However, the author found in an earlier study of offline firms that it only provides a foundation for branding activity. [5] Its effect on the other branding stages is not as strong as once thought. This seems to make sense for online firms where having a narrowly defined vision restricts potential development. A loosely defined vision that can give rise to an 'attitude' suits the organization more. 
Online companies did not have visions that tied them down to product categories or geographical markets. They had a main philosophy but the interpretation of that into strategy was flexible.

New Zealand's Jenniferann.com, the world's leading online lingerie store, has a vision of being a "strong brand" and a "women's super-store", says CEO Jenny Hannah. [25] It eventually etailed homeware and gifts as well. Although its homeware and gifts' diversification happened earlier than planned, it was still accommodated for in her vision.

nzgirl.co.nz defined itself by an attitude ("building self-esteem, self-awareness and confidence"). [26] Technically not a dot com, nzgirl's reputation is global and has been approached by international concerns interested in syndicating its distinctive teenagetargeted content. nzgirl's Jenene Crossan-Nicholls says that her business operates "flexibly" to take on "unexpected turns."

Lucire, Australasia's most widely read fashion title, is one of the very few online entrants allowed into New York Fashion Week (the other noticeable player is Condé Nast's style.com). Arriving later (1997) than its principal competitors except for harpersbazaar.com, Lucire had to differentiate, being independent and showcasing emerging talent alongside established players. It is a highly recognized brand. [27, 28] It was flexible: originally the magazine was regional but became global, when some projections did not eventuate.

The author has called his company "organic", [29] saying that an organization working online has to change with necessity and acquire competences as it develops. Lucire has gradually brought more of its skills in-house, as has Australia's Hippies, a well-known fashion brand, that began with an off-site ecommerce store and now incorporates it under its own domain.

None felt they had stepped away from their principal visions.

The founders were in their 20s. All said that their organizations reflect their personalities, as might be expected with a 'first-generation' firm. ${ }^{2}$ There was no evident positioning statement-tagline as with Saturn or Caltex, with the exception of Lucire, which uses "The global fashion magazine". However, that fails to sum up its 'attitude'.

The small sample suggests that taglines or vision statements are less important than the actions demonstrating commitment, attitude and positioning. Site content is stronger for a web-savvy public tired of the commercialism of slogans.

\subsection{Researching the venture}

In the author's earlier study, the Narver and Slater market orientation dimensions of management commitment, facilitative management and interdepartmental connectedness [30] impact on subsequent branding stages. Proper research is vital.

Larger organizations research their visions and their suitability because the personality of the organization is not the creation of the CEO alone. Fekete \& Com-

2 A firm where the founder is still the managing director, owner or chief executive. 
pany of Columbus, Ohio, has found that " 79 per cent of the CEOs selected a different personality type [for their companies] than did their team of key executives." [3I] For the smaller organizations examined, all of whom had more limited resources, research was more ad hoc and the danger of differing personalities not as great. Greater 'tightness' within the team became more important.

Generally, research was not as deep as in offline corporations, compensated for by speed, low cost and a willingness to try, since there was little existing wisdom on how to brand online then. All were active in ensuring that the research's findings would be carried through to the product, strengthening their validity.

Hannah said, "I base a lot of my business decisions on 'gut feel'. Of course, I researched my competitors and the whole internet industry. However, I am a strong believer in ... getting on with it." This reflected Lucire's gestation: research in 1996 gave indications but the product differed in execution.

As a result, there is management commitment because the $\mathrm{CEO}$ is the centre of the network and the champion of the vision, often using email as the first medium for contact.

Low cost. There is an emphasis on low cost. Hannah brought on team members on an as-needed basis, something shared with Lucire. Hippies' Vanessa Palmer kept her core web team to three although her whole staff's input is sought at meetings when changes are being made. [32] JY\&A Fonts, Australasia's leading font software company, relies on others' ecommerce operations to take care of order fulfilment and credit card processing, paying a relatively low commission compared with its offline retailers.

Close relationships. They allow people from across the organization to have input into the venture, demonstrating facilitative management. Openness is encouraged Hannah calling it "crucial" to her company's success.

Close relationships are important. As there are no formal departments, "interdepartmental connectedness" is inapplicable. Palmer says there is 'no formal structure' at Hippies. "Everyone has their own roles and responsibilities, but if someone needs help in another area, you just get in and do it."

Because they are able to find like-minded individuals more easily online, or because they rely on friends, a shared vision is quickly understood. This leads to "fun" - a word commonly found in responses - indicating tightly knit groups.

Crossan-Nicholls "surrounded myself with people that also believed in what we're doing." Lucire reports the same, beginning with its first correspondent, Sidney Morningstar, and later its fashion editor (now editor-in-chief) Simone Knol and photo editor Rebecca Thorpe. [29] As Knol, Thorpe and others emigrated, the venture changed to accommodate them while keeping its principles. Diversifying into television production, the Lucire team has ensured that the original values are retained under its New York-based creative producer Monica Parente. nzgirl is planning its own cross-media move, a strategy which will allow it to get additional readers.

There was no agreement on whether face-to-face meetings were necessary: physical and virtual techniques were employed. 
The function of departments is largely replaced by the ability to use technology. Palmer began videoconferencing in late 2000 to keep in touch with her American office. This suggests that intangibles, such as intellectual property and professional skills, in addition to brands, are valued more online than scale. The challenge will be for the organizations to retain an entrepreneurial spirit as they grow, but technology, such as videoconferencing, is aiding that.

\subsection{Branding the venture}

In online business, Olins may be right in using a more inclusive 'attitude' approach, where independent contractors, freelance workers and virtual team members are literally external to management. They take on more of the behaviours of channel members who need to be sold on the venture but are not full-time employees.

Offline, the most important aspect is facilitative management. The provision of sufficient branding material (e.g. graphics, stationery) and other resources (e.g. funding), and cooperation between management and team members, ensured strong brands. It was reflected online, concerning brand use consistency.

For the organization that has accepted a vision encompassing offline and online ventures, there are issues of:

(a) whether a brand should be built from scratch for the online medium or adapted from an offline concern and the cost of doing either;

(b) whether to adopt a different brand for the online arm; [18]

(c) how great a focus the online venture will have relative to other (offline) ones, if they exist;

(d) whether to have a different (usually global) target audience for the online venture (which leads to concerns of how high-tech the site can be), if an offline venture already exists;

(e) whether to mask its national origins through a dot com domain name;

(f) whether the brand itself is strong enough to remain online-only or whether additional media support is required (not just PR and advertising, but extending the brand into different media).

Those beginning offline adopted existing brands. Bloom Cosmetics, Evolu, Karen Walker and Zambesi ensured commonality across print and web media, furthering the belief that brands created specifically for the web that differ from their online counterparts do not contribute to brand equity. ${ }^{3}$ These organizations saw the online presence as more secondary to existing branding methods.

Online ventures had to create brands and predictably placed a greater focus on them. Unlike Amazon.com, they did not change the logo or symbol after going online.

3 Notable exceptions, such as ninemsn.com.au, the Australian portal developed by Nine Network and Microsoft, and stuff.co.nz, owned by Independent Newspapers Ltd., half-owned by News Corp., had cross-media support coupled with substantial financing. However, they target domestic audiences although their resources exceed the independent firms aiming globally. 
The brand equity associated with the original manifestation of the brand exists today. ${ }^{4}$ Lucire intentionally went with its sans serif masthead to contrast established players such as Elle, Vogue and the now-defunct Lumière. ${ }^{5}$ Careful positioning at the beginning ensured they did not have to change.

Consistency in the domain name was important. Those examined did not have a separate web brand. ${ }^{6}$ Doing so would have burdened them with the greater cost of pushing what would have effectively been two brands, diluting them both, and using funds that were scarce.

Think global, act global. Recognizing the largest market would be the United States, all stayed clear of pushing a stereotypically antipodean image. "We don't hide the fact that we are a New Zealand company," says Hannah, "however, we certainly don't promote it." Her site even adopts American spellings and like all the etailers here, quotes in US dollars. Lucire believes that the use of a New Zealand image is disadvantageous, when many believe it is rural, rather than high-tech. Hippies launched in the United States and Australia simultaneously, using common campaigns for both nations, preventing the use of an overtly Australian image.

All indicated that offline, they did not target a different audience but accepted that events and print media coverage brought them additional awareness outside their core demographics.

For them, national branding is unimportant. Their decisions point to a global society. Competing for its share of mind requires strong, internationally biased brand strategies. These businesses succeeded against traditional players because they do not rely on production techniques, capital or labour, but on brand equity and networks.

In the case of Jenniferann.com, Evolu, Karen Walker, Lucire and men's interest site eMale, the founders had prior expertise in visual communications or marketing, meaning that branding advice could be implemented without delay, reliance on outside parties and expense.

Cross-media importance. Each used a unique strategy to expose the brand, having secured internal buy-in through management commitment. Hannah went as far as changing the name of her home town, Pokeno, to Jenniferann.com for 12 months. This move attracted media, including a film crew from Japan.

Hippies enters web site awards. Such events are important to bring a human face to the ventures.

4 Only Lucire reported difficulties in controlling how others used its brand. Approved parties that linked to Lucire online did not cause any problems, but unexpected links meant the logotype had been incorrectly displayed. The company regularly 'ego surfs' and provides correct graphics for the parties who linked without permission.

5 Though still online, Lumière's content has not been updated since January 1999.

6 Examples of these extra brands include Moët \& Chandon's champagne.com, Odimo's diamond.com and La Perla's glamonweb.com.

7 The exception here is that Jenniferann.com finds that shipping from New Zealand raises its cost, although this will be remedied when Jenny Hannah opens warehouses and offices in Australia and the United States. 
They use standard methods for online promotion, including link exchanges, seeking press coverage, syndication and banner advertising. Links help positioning in search engines, which in turn help users find the sites when performing a specific search.

All try to appear in non-web media - whether through getting covered by others or starting ventures in other media - to increase potential audiences and raise their brands' profile, while retaining a team feel through careful and constant internal communication of their philosophy. Generally, few believed that an online-only presence would work.

\subsection{Image}

External audiences (in the traditional sense, viz. people who do not come under the organization's brand) must view top management as standing behind the organization's claims. This is critical when it comes to order fulfilment, overcoming normally offline or late-adopting customers' fears about credit card use on the web and returning goods. The other limbs are important, too, with facilitative management interpreted as advertising support or acquiring links for the venture.

Interdepartmental connectedness is traditionally the most important element to image, because every member of the team must live up to the ideal. [5] A variant of it - perhaps more accurately described as ensuring buy-in across the team - is reflected online.

Brand equity is built as part of the venture's image. Brand associations, proprietary brand assets, brand loyalty, perceived quality and brand awareness are all consequences [33] of the branding effort. These lead to purchases, repeated visits, registrations, recommendations (e.g. through viral email marketing ${ }^{8}$ ), bookmarking, ${ }^{9}$ linking, ${ }^{10}$ syndicating (whether formally ${ }^{11}$ or through a DIY portal page such as My

8 The encouragement of the forwarding of email messages from the venture by registered subscribers to their friends.

9 Including the addition of Active Channels on Microsoft Internet Explorer, where a user may include a small file that details the latest from a selected site and load its contents for later offline browsing.

${ }^{10}$ Including link-back programmes where users are permitted to take certain graphics or banner advertisements and link exchanges.

${ }^{11}$ For instance, sites such as Lucire and nzgirl.co.nz provide their content to others through paid and unpaid syndication arrangements. 
Netscape ${ }^{12}$ ), having parties join an affiliate programme, ${ }^{13}$ and other activities that help strengthen and propagate ${ }^{14}$ the brand.

Audiences are motivated by the need to trust the organizations they deal with, and give loyalty to them. The brand equity elements do not change online: audiences require assurance that real people, especially the founder, stand behind the product or service.

As none of the companies match large American and European groups budget-wise for promotion, getting into a typical internet user's consideration set means emphasis on below-the-line promotion. Press coverage was perfect for Hippies, producing a unique product. Domestic and American press has been "phenomenal". nzgirl differentiates on content and, in Crossan-Nicholls's words, utilizes marketing alongside events and word-of-mouth. Lucire uses alliances with related, though not supplementary, ventures such as $\mathrm{Y}_{2} \mathrm{G}$.com, a hip-hop fashion and entertainment site which syndicates its video footage, iWon.com and Yahoo!, and has used viral email marketing, encouraging users to forward Lucire update emails to friends, who then sign up as registered readers.

Table I. A selection of Lucire partner sites. Lucire has used link exchanges and closer partnerships to help its standing. It has not pursued sites that have an identical psycho- and demographic but those with related audiences that it otherwise would not have reached. A small listing of partner organizations is below.

\begin{tabular}{ll} 
Site & Niche \\
BrideSave.com & Bridal etailing \\
eMale & Men's interest and fashion \\
ID Models & Modelling \\
iWon.com & General audiences \\
NYSALE.com & Sales in tri-state area \\
Sirenne & New women's interest magazine from JY\&A Media, summer \\
& 2OOI launch \\
& \\
\hline
\end{tabular}

${ }^{12}$ My Netscape allows users to select "channels" to add to a customized homepage.

${ }^{13}$ Essentially an online sales-commission programme where individuals set up "shops" on their own sites that sell the venture's goods, using coding and branding provided by the venture. The most successful example is Amazon.com's affiliate programme, duplicated by its UK and German subsidiaries.

14 Some users will (usually illegally) take a site's logo and use it for linking to the site from their own pages. This phenomenon means that organizations need to keep a careful watch over how their brands are used. Not only can the user's pages provide improper associations (such as online adult magazines) but they can misuse the logo or symbol through cropping, resizing and other techniques. Some companies, such as the author's, regularly "ego-surf" (check for their own names through search engines) to patrol and enforce trademark use. 
Although none directly addressed the issue, they have been careful not to appear too large as modern consumers react against corporations perceived to be exploitative. ${ }^{15}$ This has a negative effect internally, too. Online ventures risk losing team spirit, the very thing that helped their growth.

The "attitude" referred to by Olins is apparent. Although no external audiences were researched, respondents said that they believed they conveyed a fun or supportive image. These were elements of their attitudes. Other elements, like morality or justice, play their part. Respondents appear keen to counter the dishonesty that audiences perceive of large corporations, a trend that began in the I990s and offline.

Therefore, nzgirl aims to be its audience's "'best friend' ... they can come and be anonymous, yet get advice, make friends, be entertained, gain information, not be threatened or made to feel bad. ... They can rely on us to be here 24-7." Lucire ensures timely replies to readers' queries and has a policy of helping enquiring students with their research.

The trend toward caring brands will continue - and there is evidence to show that consumers' preference for them is nothing new. [IO, 34] What has changed is access to information that help consumers make informed decisions in an increasingly global society. Every respondent understands that the image must be backed up by substance. As the ventures can remain small using technology as a bridge, CEOs will be able to respond directly to their audiences and understand how they are doing image-wise, continuing the environmental scanning required to focus or reposition their brands without added expense. Additionally, this allows them to keep in touch with changing trends and constantly acquire knowledge about their operations. It is a variant of the traditional notions of market orientation, [30] stripping out research intermediaries so that top management has first-hand contact with audiences.

Unless there is a change in their corporate structure, such as acquisition or merger, these antipodean online ventures should be able to continue their growth by being small, moving quickly, and thinking globally. They are typical of the organizations that can survive alongside large, merged corporations because of careful branding, specialization, and managerial responsibility and responsiveness.

\subsection{Performance}

Since numerous online ventures do not post a profit (e.g. Amazon.com), performance cannot always be measured in strict financial terms. With smaller privately held companies, financial data are not available. In subjective or strategic terms, visitor numbers, rankings vis-à-vis its competitors, number of registered users and reputation in the industry (judged by links to the site, number of parties syndicating content or

15 At the time of writing, an email attacking Nike's alleged use of sweatshop labour is being circulated. Other urban myths are reported as fact - one 'cookie recipe' blames NeimanMarcus for overcharging. Because inaccurate news like this can travel quickly, no organization wishes to be the target of fictions. 
entering into affiliate programmes, or by the view from independent industry observers) are valuable indicators.

Respondents were pleased with their ventures. Jenniferann.com has met Hannah's expectations "insomuch as we enjoy a steady rate of growth, exceptionally good feedback and overwhelming support from our suppliers." Crossan-Nicholls says that nzgirl is "so much more than we could have ever hoped for." In strategic terms, there was good feedback.

Web rankings for the sites examined [35] are shown below in bold. These are slightly more objective, yet they must be interpreted relative to their industry and their starting dates.

"Links in" indicates the number of links to the site. Some better-capitalized US and European competitors selected by the author are listed below each for comparison. Domestically targeted sites are also listed where applicable.

The table does show that despite generally later starts, less capitalization and fewer resources, antipodean sites have fared well and better than those targeted domestically, with few exceptions. The importance of differentiation and cross-media presence is highlighted.

Table 2. Rankings of sites, according to Alexa Internet, 26 April $200 \mathrm{I}$

\begin{tabular}{|c|c|c|c|}
\hline Site & $\begin{array}{l}\text { Date online } \\
\text { at current URL }\end{array}$ & $\begin{array}{l}\text { Links in } \\
{[34]}\end{array}$ & Alexa ranking \\
\hline Bloom Cosmetics & & 3 & 328,684 \\
\hline Stila Cosmetics & April 1998 & 37 & I66,919 \\
\hline eMale & & & 346,575 \\
\hline Breaka (XM, AU) & & & 521,592 \\
\hline$G Q \mathrm{UK}(\mathrm{XM})$ & April I998 & 378 & 24,638 \\
\hline Razor (XM) & & I & $\mathrm{I} 7,424$ \\
\hline SharpMan (OO) & August 1998 & IOO & I75,II4 \\
\hline $\begin{array}{l}F H M \text { Australia (XM, } \\
\text { AU) }\end{array}$ & & & $86, \mathrm{I} 2 \mathrm{I}$ \\
\hline Evolu & December $1998^{16}$ & & $4,681,028^{\star \star}$ \\
\hline Hippies & March 1998 & 86 & 608,952 \\
\hline Hanes Hosiery & October 1995 & 74 & $297,83 \mathrm{I}$ \\
\hline Wolford & January I997 & I70 & 54,335 \\
\hline $\begin{array}{l}\text { Jenniferann.com } \\
\text { Glam on Web (La Perla) } \\
\text { No Regrets }\end{array}$ & June 1999 & 85 & $\begin{array}{r}325,978 \\
48,172 \\
95,393\end{array}$ \\
\hline
\end{tabular}

${ }^{16}$ Network Solutions Whois record domain registration date, not when the web site was launched. 
IM Imports (AU)

JY\&A Fonts
Agfa Monotype
Font Bureau
International Typeface
$\quad$ Corp.
Hoefler Type Foundry

Karen Walker

Anna Sui October 1996

\section{Lucire}

Elle.com (XM)

Fashion Live (OO)

Hint (OO)

style.com (Condé Nast, XM)

Fashion New Zealand

$$
\text { (NZ) }
$$

March 1997
September 1995

April 1997

January 1996

February $2000^{17}$

\section{I8}

$3,8 \mathrm{OI}$

$134,669^{\star}$

269,266

$436 \quad 192,982$

nzgirl

gURL (OO)

Teenmag.com (XM)

Teen-net (OO)

girl.com.au (AU)

Zambesi

$\begin{array}{lrr}\text { December I998 } & \mathbf{8 I 6} & 36,533 \\ \text { April I996 } & 4,937 & 5,248 \\ \text { November I997 } & 72 & 34,082 \\ \text { October I997 } & \mathrm{I}, 039 & 48,425 \\ & & \\ \text { April 2000 } & 97 & 3,869 \\ & & \\ \text { I998-9 } & & \text { IO5,095 } \\ & & \\ \text { December I999 [35] } & & 508,642 \\ \text { December I997 } & 35,222 & 5,182 \\ \text { January I996 } & \mathrm{I}, 793 & 4,67 \mathrm{I} \\ \text { July I996 } & \mathrm{I}, \mathrm{IO} 8 & 36 \mathrm{I}, 836 \\ & & 5 \mathrm{I} 8,508\end{array}$

$1,226,760^{\star \star}$
Key

$\mathrm{XM}=$ cross-media

$\mathrm{OO}=$ online-only

$\mathrm{NZ}=$ domestically targeted, New Zealand

$\mathrm{AU}=$ domestically targeted, Australia

* This figure is inaccurate for comparison purposes as it has been boosted by JY\&A's Consulting and Media divisions. Comparison to the International Typeface Corp. site may be fairer considering both JY\&A and ITC store online magazines under their domains.

$\star \star$ Intended as brand support and brochureware rather than the main communications channel with audiences, hence the low ranking.

17 Ibid. 


\section{Conclusions}

The organizations examined indicate that the practice of identity and branding online has not changed drastically from its offline progenitor. It continues to revolve around differentiation and trust, as it always has. Consumers depend on both. Technology has become an intermediary linking the CEO and the vision to the public, with fewer distractions arising internally, and vice versa.

Larger, traditional organizations have trouble communicating the vision because the message can be lost through the number of staff and the expense required to communicate to them. Management tends to be distant from consumers and their impression of the organization.

Antipodean organizations are excellent examples because there are national traditions of innovation and independence. [37] The purity of this concept has been carried through more strongly online. The do-it-yourself nature of Australasians seems particularly suited to the medium. Visions must be strong, but organizations must exhibit flexibility and acquire competences as technology changes increasingly more quickly. ${ }^{18}$

They have each tapped in to an increasing cynicism against big business. In many cases, they were part of their own demographic, using their own needs to form strategy. [38] The brands they created stand independently and have an entrepreneurial image. They generally place little emphasis on taglines, another differentiating factor against larger, traditional enterprises. Instead, there is a reliance upon a brand attitude.

Skilful branding was imperative given the limits to expenditure. Costs are kept very low while management structures are organic and flat.

As the organizations grow, the entrepreneurial spirit can be retained by technology. Tools such as videoconferencing and the lower prices of telephone calls allow them to keep a team spirit without adding on additional personnel who risk diluting or misunderstanding the vision.

Consistency is paramount. There must be no difference in the way the organization is perceived on- and offline, hence the establishment of online-only brands has been avoided by all the respondents. All recognize the emergence of a global consumer society.

\section{I Implications}

Cross-media presence was considered important. However, implications arise here. Large corporations can afford cross-media promotions. These organizations tend to be based in a single country so offline promotions will be domestic and below-the-line, unless they can create events of international interest, such as Hannah's town-renaming or Lucire's use of Yahoo! Full Coverage to generate hits. The study shows that these are rare although they cement the case for strong brand foundations as well as

18 This must be tempered by the need to reach emerging economies, whose telecommunications infrastructures and computers may not be able to handle high-bandwidth transmissions. 
the belief that intellectual capital is the driving resource. They have certainly created reputations for themselves as visionaries. To continue this, the antipodean organization must be prepared to use ingenuity to create global interest, otherwise it risks being lost amongst organizations whose promotional budgets alone rival its capital. This issue aalso brings the possibility of mergers, acquisitions and alliances.

If "fun" is a critical part of these brands, then there is a possibility that they are visited because they provide entertainment. [39] Those that are not already providing media services such as nzgirl, eMale and Lucire may find that this is a possible route to generate consumer interest.

A bimodal distribution of organizations, where there are large conglomerates and boutique players, but no mid-size firms, looks set to continue for the foreseeable future, with one difference: the boutique players, which the Australian and New Zealand firms are in resource terms, must think globally and reach the same potential audience. This will be done through coordinated marketing and responsiveness, but most importantly, their ability to communicate brand values to publics - including the media - and shift more quickly than the larger corporations. As Table 2 showed, the entrepreneurs have been able to compete, largely because the CEOs remained aware of changes.

A further issue lies with the change from the first to the second generation. Although there is nothing to suggest that the respondents will leave their companies, succession must play on their minds. While they are sure that their creations will continue, they have become intertwined with their brand. The face of Jenniferann.com is Jenny Hannah. Vanessa Palmer appears in her own promotions. Since they were the ones who showed management commitment, will team members who may have only had email contact be prepared for the change? And will the brand need to change?

If there is such cynicism amongst the public about businesses, will the internet remain an effective tool? As mentioned, some web surfers go online with tightly defined criteria. They do not have the same fascination for the new medium as the 20something originators of the successful antipodean brands. Capturing the hearts of today's teen audience to ensure continued web patronage is an issue for all but nzgirl, which already targets that age group.

The study shows that the online public has the same concerns as the offline one about corporate citizenship and trust. The companies' moves to cross-media presences indicate that they see a merging of the 'wired' and 'unwired'. Both must be reached with strong, branded campaigns. They also cater for a global audience, but none have branched into non-English sites, which needs to be remedied with a new set of competences, while ensuring the brand philosophies 'translate' into another culture.

Thus, the 'think global, act global' stance could have an Achilles' heel. However, it has enabled the organizations to recognize the potential of global markets and forces such as harmonization and a borderless internet. Table 2 indicates that locally targeted sites cannot realize visitor numbers if the web is their primary medium. 'Thinking local' should be the realm of organizations that are inherently local, such as city councils or groups that depend on physical location.

The attraction of analysing the antipodean firm is the small size of the region and high per capita internet usage. Australasians have also been immune to the cynicism 
that set in when some likened the internet gold rush to tulipomania. Despite their later adoption, there are lessons for all organizations wishing to work commercially on the web or field coordinated marketing campaigns that recognize the growing internet public.

\section{References}

I. Hagel, J. and Singer, M.: Unbundling the Corporation. McKinsey Quarterly, No. 3 (2000) I48-I6I

2. Yan, J.: Boo.com Boo Hoo. CAP Online (i9 May 2000) http://jyanet.com/cap/2000/ 0518ob0 . shtm1; Emmott, B. (ed.): Business This Week. The Economist (27 January 200I); Klein, A.: Disney Red-Lights Go.com Site. The Washington Post (30 January 200I) EI2. Cf. King, C.: Walt Disney Internet Group Shows Financial Gain. InternetNews.com (9 November 2000) http: //www. internetnews.com/fina-news/article/ 0, ,5_507471,00.html; Lambeth, J.: Surviving the Big Squeeze. Electronic Telegraph (I9 October 2000) http://www.telegraph.co.uk

3. Frankel, R. (ed.): I-Branding Digest, No. 8 (I6 January 200I) http:// list.audettemedia.com/archives/archives.html

4. Interview by the author with Wally Olins (I9 June 2000)

5. Yan, J.: The Attitude of Identity. Desktop (October 2000) 26-3I

6. Olins, W.: Trading Identities: Why Countries and Companies Are Taking on Each Other's Role. The Foreign Policy Centre, London (1999)

7. Olins, W.: The New Guide to Identity. Gower Publishing, Aldershot (1995)

8. Yan, J.: Corporate Identity: Its Effects on Business Performance-a Thesis Submitted for the Master of Commerce and Administration Degree. Victoria University, Wellington (1999)

9. White, I.: Learn to Read the Sign Language. Desktop (September 1999) 66-69

Io. Engel, J., Blackwell, R. and Miniard, P.: Consumer Behavior, 6th edn. Dryden Press, Chicago (I990); q.v. Barkow, T.: The New New Ecommerce. Webreview.com (26 January 200I) http://www.webreview.com/soapbox/2001/01_26_01.shtm1

II. Farquhar, P. H.: Managing Brand Equity. J. Ad. Res. (August-September 1990) RC-7-I2

I2. Aaker, D.: Building Strong Brands. Free Press, New York (I99I)

I3. Cavusgil, S. T. and Zou, S.: Marketing Strategy-Performance Relationship: an Investigation of the Empirical Link in Export Market Ventures. J. Mktg., 58 (1994) I-2I

I4. Dau, R. and Thirkell, P.: The Relationship Between Marketing Orientation and Export Performance: Further Empirical Evidence. Proceedings of the 1996 Australia-New Zealand Marketing Educators' Conference. Wellington (1996) 369-386

15. Klein, N.: No Logo: Taking Aim at the Brand Bullies. Picador, New York (2000)

I6. Combining Olins, W.: The New Guide, op. cit.; and after Littler, D.: Editorial. Int. Marketing R., Vol. I2, No. 2 (1995) 4-8, referencing Kim: A Perspective on Brands, J. Consumer Marketing, Vol. 7, No. 4 (1990) 63-7; and American Marketing Association: Marketing Definitions: a Glossary of Marketing Terms in Kotler, P.: Marketing Management: Analysis, Planning, Implementation and Control. 6th edn. Prentice Hall, Englewood Cliffs and London (1988) 
I7. Cahalan, A., as quoted in Yan: The Attitude of Identity, op. cit.

I8. Rochman: Marketing Guru Al Ries Talks about the Web. Webreview.com (28 July 2000) http://www.webreview.com/2000/07_28/strategists/07_28_00_3.shtml

19. Nike Ten-Year Financial History. Nike Inc., Beaverton (2000) http://nikebiz.com/ invest/ar_00/financials/10_year_history.pdf

20. Levi Strauss \& Co.: 2000 Annual Report. Levi Strauss \& Co., San Francisco (2000); Branded. BBC Television, London (1996); Terpstra, V. and Sarathy, R.: International Marketing, 5th edn. Dryden Press, Chicago (199) 488-489

2I. Gwartney, J. and Lawson, R.: Economic Freedom of the World: 1997 Annual Report. The Fraser Institute, Vancouver (1997)

22. Bryan, L. and Fraser, J.: Getting to Global. McKinsey Quarterly, No. 4 (1999) 68-8I

23. JY\&A Consulting: JY\&A Consulting Profile. JY\&A Consulting, Wellington (2000)

24. Margulies, W.: Making the Most of Your Corporate Identity. Harvard Bus Rev, Vol. 55, No. 4 (1977) 66-72

25. Email interview with Jenny Hannah, CEO, Jenniferann.com (26 February 200I)

26. Email interview with Jenene Crossan-Nicholls, Publisher, nzgirl.co.nz (I2 February 200I)

27. Ptasznik, J. (ed.): Fashion Websites: the Year of Truth. Visual Arts Trends, Electronic Edition, No. eS2O (200I) http://www.visualartstrends.com/Ea/Ea6/eS20fashion.html

28. For example, Galaxy.com: Galaxy.com Fashion Report. Galaxy.com, Franklin (2000); Wiley, L.: The A-List. Access (29 April 200I); Vidal, J.: The Web that Jack Built. Flair Supplement, The Evening Post (5 December 2000) 8

29. Martinkus, A.: An Open Mind and a Global Company. Desktop (September 1999) 46-47

30. Narver J. and Slater, S.: The Effect of a Market Orientation on Business Profitability. J. Mktg. 54 (October 1990) 20-35

3I. Fekete \& Co.: Companies Are People, Too. Fekete \& Co., Columbus (1997)

32. Email interview with Vanessa Palmer and Rhiannon Davies of Hippies (26 February 200I)

33. Cadogan, J. and Diamantopoulos, A.: Narver and Slater, Kohli and Jaworski and the Market Orientation Construct: Integration and Internationalization. J. Strategic Mktg. 3 (I995) 4I-60; Jaworski, B. and Kohli, A.: Market Orientation: Antecedents and Consequences. J Mktg. 57 (July I993) 53-70

34. Yan, J.: The Moral Globalist: Making Globalization Work. CAP Online (2 May 200I) http://jyanet.com/cap/2001/0502fe0.shtm1

35. Alexa Internet Rankings. Alexa Internet, San Francisco (26 April 200I) http:// www.alexa.com

36. Knol, S. (ed.): Teen Portal nzgirl Gets New Look. Lucire (8 February 200I) http:// lucire.com/news.html

37. Ministry of Commerce: Bright Future. Ministry of Commerce, Wellington (I999)

38. Bhide, A.: How Entrepreneurs Craft Strategies that Work. Harvard Bus. Rev., Vol. 73, No. 2 (I994) I5O-I6I

39. Yan, J.: Range on the Home. Visual Arts Trends, No. 3 S (December 2000) 63-65 